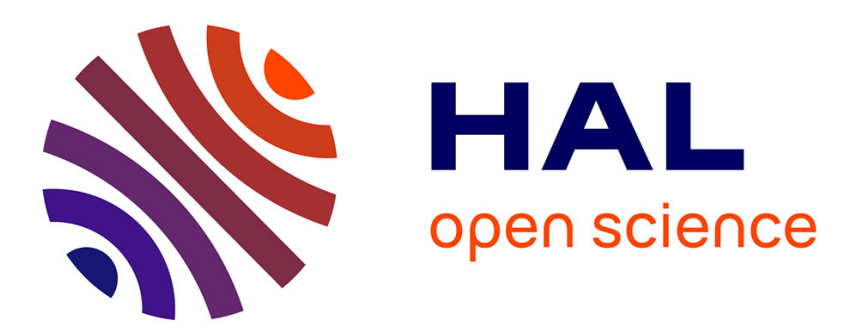

\title{
Investigation of the oxygen reduction activity on Silver - a rotating disk electrode study
}

Gustav K.H. Wiberg, Karl J.J. Mayrhofer, Matthias Arenz

\section{To cite this version:}

Gustav K.H. Wiberg, Karl J.J. Mayrhofer, Matthias Arenz. Investigation of the oxygen reduction activity on Silver - a rotating disk electrode study. Fuel Cells, 2010, 10 (4), pp.575. 10.1002/fuce.200900136 . hal-00552362

\section{HAL Id: hal-00552362 \\ https://hal.science/hal-00552362}

Submitted on 6 Jan 2011

HAL is a multi-disciplinary open access archive for the deposit and dissemination of scientific research documents, whether they are published or not. The documents may come from teaching and research institutions in France or abroad, or from public or private research centers.
L'archive ouverte pluridisciplinaire HAL, est destinée au dépôt et à la diffusion de documents scientifiques de niveau recherche, publiés ou non, émanant des établissements d'enseignement et de recherche français ou étrangers, des laboratoires publics ou privés. 


\section{Investigation of the oxygen reduction activity on Silver - a rotating disk electrode study}

\begin{tabular}{|r|l|}
\hline Journal: & Fuel Cells \\
\hline Manuscript ID: & fuce.200900136.R3 \\
\hline Wiley - Manuscript type: & Original Research Paper \\
\hline Date Submitted by the \\
Author: & $12-$ Mar-2010 \\
\hline Complete List of Authors: & $\begin{array}{l}\text { Wiberg, Gustav; Technische Universität München, Lehrstuhl } \\
\text { Physikalische Chemie } \\
\text { Mayrhofer, Karl; Technische Universität München, Lehrstuhl } \\
\text { Physikalische Chemie } \\
\text { Arenz, Matthias; Technische Universität München, Lehrstuhl } \\
\text { Physikalische Chemie }\end{array}$ \\
\hline Keywords: & $\begin{array}{l}\text { Ag Catalyst, Alkaline Media, Fuel Cell Electrode, PEM Fuel Cell, } \\
\text { Oxygen Reduction Reaction }\end{array}$ \\
\hline
\end{tabular}

\section{s ScholarONE" \\ Manuscript Central}




\author{
Gustav K.H. Wiberg ${ }^{\mathrm{a}}$, Karl J.J. Mayrhofer ${ }^{\mathrm{a}, \mathrm{b}}$ and Matthias Arenz ${ }^{\mathrm{a}, \mathrm{c} *}$ \\ ${ }^{\text {a }}$ Technische Universität München, Garching, D-85748, Germany \\ Lehrstuhl für Physikalische Chemie \\ ${ }^{\mathrm{b}}$ present address: MPI für Eisenforschung \\ Abt. Grenzflächenchemie und Oberflächentechnik \\ ${ }^{c}$ new affiliation: Department of Chemistry, CS06, University of Copenhagen, Universitetsparken 5, DK-2100 \\ Copenhagen $\varnothing$ Denmark \\ * to whom correspondence should be addressed: $\underline{\text { m.arenz @ kemi.ku.dk }}$
}

Keywords: oxygen reduction reaction (ORR), Silver (Ag), alkaline electrolyte, non-platinum metal catalyst, electrochemically accessible surface area (ECA)

\begin{abstract}
In this study the oxygen reduction reaction (ORR) is investigated on a nanoparticulate Silver electrocatalyst in alkaline solution. The catalytic activity of the catalyst is determined both in terms of mass activity as well as specific activity and turn over frequency, respectively. It is demonstrated that the established mass activities are independent of the applied catalyst loading, an essential requirement for a reasonable analysis. The determination of the electrochemically active surface area (ECA) or the number of electrochemically accessible sites $\left(\mathrm{N}_{\mathrm{ECAS}}\right.$ ), respectively, is performed by the underpotential deposition of lead. The obtained value of the activity is compared to activities of polycrystalline Silver and Platinum measured in the same electrolyte, as well as to literature data.
\end{abstract}

\title{
Introduction
}

Even though fuel cells (FC) were invented a long time ago and foreseen to be "tomorrows" energy converter of choice since the last decades, they have not yet arrived on a broad front. In the case of mobile applications, with size scaling from handheld devices up to automobiles, the cost of energy conversion of a state of the art proton exchange membrane (PEM) FC so far exceeds that of other competitive mobile technologies. One of the main reasons for this is the high price of the noble metal catalyst of FC's. In an attempt to reduce costs, non-platinum catalysts might be a possible alternative [1,2]. Therefore also alkaline based FC have recently re-gained attention due to the fact that a variety of cheaper non-platinum metals, such as silver, nickel and cobalt, or even metal-oxides are reported to be active for catalyzing the essential oxygen reduction reaction [3-5].

In order to compare different electrocatalysts, a common methodology for their analysis is required. As pointed out in the review on high surface area catalysts by Gasteiger et al. [6], even for the case of Pt based 
electrocatalysts the reported activities deviate from each other by more than one order of magnitude; regardless of originating from rotating disk electrode (RDE), flow cell or membrane electrode assembly (MEA) measurements. Bearing in mind that these discrepancies impede an efficient comparison, Mayrhofer et al. [7] recently proposed a set of guidelines for the characterization of Pt based catalysts by the thin-film RDE methodology. These guidelines include, that the electrochemically active surface area (ECA) has to be evaluated by applying a proper method that also considers the capacity of the support, and that the ECA has to be linear dependent on the loading [7]. The comparison of electrocatalysts of different classes, i.e. non-platinum and platinum based electrocatalysts, and the judgment of their prospect is even more difficult. In this respect the necessity of a common methodology in catalyst characterization as well as the importance of benchmark activities cannot be enough emphasized. One fundamental problem in the comparison of different catalysts is the definition and determination of the ECA used to evaluate the specific activity; as the meaning of real surface area depends on the method of measurement, on the theory of this method, and on the conditions of application of the method [8]. For Pt based catalysts, the ECA is determined by the stripping charge of underpotentialdeposited hydrogen $\left(\mathrm{H}_{\text {upd }}\right)$ or oxidation of an adsorbed $\mathrm{CO}$ monolayer assuming a one to one ratio of the adsorbates and Pt atoms [9]. However, for non-platinum metal catalysts these rather straightforward methods are in general not feasible. A range of alternatives has been reviewed by Trasatti and Petrii [8], suggesting for example under potential deposition (upd) of foreign metals for metal nanoparticulate systems. The methodology of metal upd for the ECA determination has already been successfully applied by Green and Kucernak [10] in the case $\mathrm{Cu}_{\text {upd }}$ on PtRu alloy catalyst. For Ag based catalysts, $\mathrm{Pb}_{\text {upd }}$ [11] as well as $\mathrm{Tl}_{\text {upd }}$ [12] are feasible options, both yielding corresponding results.

The scope of this article is to present a thorough characterization of Silver based electrocatalysts for the ORR in alkaline electrolyte. Extending the guidelines for the activity determination by the thin-film RDE technique of Pt based catalysts and applying an active compensation of the solution resistance, we characterize a silver nanoparticle catalyst and polycrystalline (PC) Ag in $0.1 \mathrm{M} \mathrm{KOH}$ solution. An underpotentially deposited lead monolayer is stripped of the catalyst in a linear potential sweep for the determination of the number of electrochemical accessible surface sites. The obtained results of the ORR activity are compared to those of PC Pt measured in the same electrolyte as well as literature values.

\section{Experimental}

All electrochemical measurements were conducted in two separate, 3-compartment Teflon cells, previously described in refs. [9, 13, 14], using a rotating disk electrode setup with rotation control (Radiometer Analytical, France) and a Potentiostat (Princeton Applied Research, USA). The electrolyte solutions: $0.1 \mathrm{M} \mathrm{KOH}$ and $0.1 \mathrm{M}$ $\mathrm{KOH}+125 \mu \mathrm{M} \mathrm{Pb}\left(\mathrm{NO}_{3}\right)_{2}$ were prepared using Millipore water (Resistivity $=18.2{\mathrm{M} \Omega \mathrm{cm}^{-1}}^{-1}$ TOC $<5 \mathrm{ppb}$ ), $\mathrm{KOH}$ pellets (Merck, Suprapure) and Lead(II)nitrate salt (Merck, analytical grade). During measurements, the electrolyte was purged with either Argon or Oxygen (Airgas, purity grade 5.0). A Standard Calomel Electrode (SCE) was employed as a reference electrode. However, the reversible potential of hydrogen oxidation/reduction was determined for each measurement, and all presented data are given with respect to the Reversible Hydrogen Electrode (RHE). The working electrodes used are Ag, Pt and Glassy Carbon (GC) disks (each $\varnothing=5 \mathrm{~mm}$, $\mathrm{A}=0.196 \mathrm{~cm}^{2}$ ), the sides coated with epoxy-resin (to minimise parasitic currents) and mounted into Teflon RDE 
tips. The glassy carbon disk was cleaned by polishing, placing into a sonic cleaner, and finally placing it for 5 min into concentrated perchloric acid.

The Silver catalyst was provided in powder form by Umicore AG \& Co. KG having an average particle size of about $100 \mathrm{~nm}$. It was suspended in Millipore water, dispersed by a 2 seconds-insertion into an ultra sonic cleaner and thereafter kept on rotation by a magnetic stirrer. An aluminium foil covered the glassware in order to protect the silver catalyst from light. By these measures, agglomeration of the particles was reduced and the upper limit of the catalyst solution lifetime was one week; however, by keeping the solution longer in the sonic cleaner or unprotected from light, a visible degradation appeared already after a few hours. The catalyst layers were prepared by pipetting 20-40 $\mu \mathrm{l}$ catalyst solution onto an electrochemically oxidised GC disk (100 mA for $5 \mathrm{~min}$ in 2 electrode setup). Thereafter the electrode tip was put in a light sheltered dryer under $\mathrm{N}_{2}$-atmosphere. Due to the hydrophilic nature of the oxidised GC reproducible smooth catalyst layers could be produced without the usage of any additives, furthermore the oxidation also enhances the sticking of the silver particles onto the GC $[15,16]$.

Prior to each measurement the solution resistance $\left(\mathrm{R}_{\mathrm{u}}\right)$ [17] from the working electrode to the Luggin capillary was determined using a AC signal $(5 \mathrm{kHz}, 5 \mathrm{mV})$, and thereafter electronically compensated for by a positive feedback scheme. [6] In our setup, the typical $\mathrm{R}_{\mathrm{u}}$ was around $10 \Omega$, however, in some cases values above $20 \Omega$ were determined, which have a large effect if no compensation scheme is used. A complete guideline for thin film RDE measurements will be reported elsewhere. The CV and ORR measurements in $0.1 \mathrm{M} \mathrm{KOH}$ were conducted in the $\mathrm{Pb}$ free cell, prior to the surface area determination performed in a separate cell, thus preventing any $\mathrm{Pb}$ contamination that could affect the activity measurements.

\section{Results \& Discussion}

Prior to the ORR and surface site determination measurements, the catalyst samples were characterized by cyclic voltammetry in Ar saturated solution (not shown). In order to avoid any potential induced changes of the catalyst, the potential window was kept in between 0.00 and $1.05 \mathrm{~V}_{\mathrm{RHE}}$. Both NP Ag and PC Ag exhibit no specific features in this region, so mainly capacitive currents were observed in agreement with previous findings [18-20]. Hydrogen evolution occurs at more negative potentials than $-0.3 \mathrm{~V}_{\mathrm{RHE}}$, whereas at potentials more positive than $1.05 \mathrm{~V}_{\mathrm{RHE}}$, large oxide features can be observed. These silver oxide can be formed irreversibly, indicated by a white staining of the PC Ag-electrode, and leads to a roughening of the surface [21-23].

\section{Oxygen reduction activity}

ORR measurements were conducted in a $\mathrm{Pb}$ free cell by recording polarization curves in oxygen saturated $0.1 \mathrm{M}$ $\mathrm{KOH}$ solution between -0.3 and $1.050 \mathrm{~V}_{\mathrm{RHE}}$, with active $\mathrm{R}_{\mathrm{u}}$-compensation, see Figure 1. Cycling below $0.0 \mathrm{~V}_{\mathrm{RHE}}$ results in a considerable increase in the ORR activity, which can be associated with the reduction of the $\mathrm{Ag}$ surface, as reported previously $[3,24]$. The lower potential limit of $-0.3 \mathrm{~V}_{\mathrm{RHE}}$ was chosen since it leads to a maximized ORR activity of the Ag catalysts, while at the same time avoiding a major detachment of NP Ag from the GC electrode, which was observed at even lower potentials.

In Figure 1A the ORR polarization curves of NP Ag for 3 different loadings are compared to the ones of PC Ag and bare GC. In order to extract the faradic current $i_{f}$ all polarization curves are corrected for capacitive currents by subtracting the corresponding blank CV recorded in Ar saturated solution. From Figure 1A it is discernable that the GC has only a negligible influence on the ORR polarization curves of NP Ag, since no oxygen reduction 
occurs above $0.7 \mathrm{~V}_{\mathrm{RHE}}$. Furthermore, it can be observed that with increasing catalyst loading, the polarization curves shift towards higher potentials as expected. This effect was utilized to adjust the region for the determination of the ORR activity to potentials relevant for fuel cell applications. In the case of NP Ag for instance the kinetic current regime for a loading of $200 \mu \mathrm{g} \mathrm{cm}^{-2}$ lies above $0.8 \mathrm{~V}_{\mathrm{RHE}}$ and thus in the potential region of interest. At potentials below $0.6 \mathrm{~V}_{\mathrm{RHE}}$ the current is limited by diffusion of oxygen towards the electrode surface $\left(\mathrm{i}_{\mathrm{dl}}\right)$, and no kinetic data of the oxygen reduction were extracted. The analysis of a Levich plot of $\mathrm{i}_{\mathrm{dl}}$ at various electrode rotation rates $(\omega)$ (not shown), indicates that no diffusion resistance occurs. Given the theoretical value of the diffusion limited current for a 4 electron process of $4.4 \mathrm{~mA} \mathrm{~cm}^{-2}$ at $900 \mathrm{rpm}$, calculated using the Levich equation and literature data; i.e. $\mathrm{O}_{2}$-solubility $\left(1.2 * 10^{-6} \mathrm{~mol} \mathrm{~cm}^{-3}\right)$ [25], $\mathrm{O}_{2}$-diffusion-coefficient $\left(2.0^{*} 10^{-5} \mathrm{~cm} \mathrm{~s}^{-2}\right)$ [25], and viscosity of the electrolyte $\left(1.0 \times 10^{-2} \mathrm{~cm}^{2} \mathrm{~s}^{-1}\right)$ [25]; the measured diffusion limited current obtained for a loading of $200 \mu \mathrm{g} \mathrm{cm}^{-2}$ as well as for PC Ag deviates less than $10 \%$ from the theoretical value in accordance to the guidelines for Pt based catalysts [7]. For catalyst loadings of 50 and $100 \mu \mathrm{g} \mathrm{cm}^{-2}$ the diffusion limited currents deviate slightly more from the theoretical value, indicating an incomplete coverage of the GC with Ag particles.

In the potential region of mixed diffusion and kinetically controlled current the kinetic oxygen reduction current density, $J_{k}$, was calculated and utilized to construct a Tafel plot ( $\log J_{k}$ vs. E). Figure 1(B) illustrates the corresponding Tafel plot of the measured data in Figure 1(A). Within a certain potential range, 0.7 to $0.9 \mathrm{~V}_{\mathrm{RHE}}$, the curves for the NP Ag recorded for different catalyst loadings are parallel to each other with a constant Tafel slope of $120 \mathrm{mV} \mathrm{dec}^{-1}$, as determined by a linear regression of the data. The current densities are shifted by the respective factor in the loading. This scalability of the results with the loading is an important prerequisite for a reasonable analysis by the thin film RDE method. Only then the true catalytic activity of an electrocatalyst towards the ORR, expressed by two equally important characteristics, namely the mass specific activity (in short mass activity) and the surface area specific activity (specific activity), can be determined from the Tafel plot.

\section{Mass activity}

The mass activity $\left(\mathrm{J}_{\mathrm{k}: \mathrm{m}}\right)$, i.e. the normalization of the kinetic current to the catalyst loading $\left(\sigma_{\mathrm{L}}\right)$, is especially of economic importance, since it directly indicates the cost of energy conversion related to the deployed amount of catalyst. A scalability of the total kinetic current with the catalyst loading, as obtained for the NP Ag in this study, guarantees that all the catalyst is used in the reaction. The mass activity of the NP Ag catalyst determined by averaging 12 samples of several different loadings in the range from 50 to $200 \mu \mathrm{g} \mathrm{cm}^{-2}$ is plotted in Figure 2 . At $0.9 \mathrm{~V}_{\mathrm{RHE}}$ the mass activity is $2.0 * 10^{-6} \mathrm{~A} \mathrm{\mu g}^{-1}$. The standard deviation of the NP Ag measurements in the potential region of interest is less than 10\%. This small error in mass activity over a mass span of a factor of 4 additionally proves the full usage of the catalyst.

\section{Determination of electrochemically accessible sites}

The standard Pt surface area determination techniques $\mathrm{CO}$ and $\mathrm{H}_{\text {upd }}$ stripping often cannot be applied for nonplatinum catalysts, as they are generally inactive towards these reactions. Consequently for each type of catalyst a suitable surface area determination technique has to be explored [8]. For the Ag electrodes in this study $\mathrm{Pb}_{\text {upd }}$ stripping (1), and for additional comparison the reduction of $\mathrm{Pb}(\mathrm{IV})$, are implemented.

$$
\begin{aligned}
& \mathrm{Pb}_{(\mathrm{S})}+2 \mathrm{H}_{2} \mathrm{O} \leftrightarrow \mathrm{HPbO}_{2}^{-}+3 \mathrm{H}^{+}+2 \mathrm{e}^{-} \quad \mathrm{pH}>10 \\
& 4 \\
& \text { Wiley-VCH }
\end{aligned}
$$


The underpotential deposition of $\mathrm{Pb}$ on $\mathrm{Ag}$ has been described before [26, 27]. A monolayer of $\mathrm{Pb}$ can be deposited onto an Ag electrode at potentials more positive than expected by the equilibrium potential for bulk deposition. In order to form a complete monolayer of $\mathrm{Pb}$, different deposition potentials $\left(\mathrm{E}_{\mathrm{d}}\right)$ were chosen as negative as possible, while at the same time avoiding $\mathrm{Pb}$ multilayer deposition. Latter introduces an additional peak in the stripping voltammogram at lower potentials (see Figure 3A), and thereby leads to an overestimation of the active surface area. Furthermore, the deposition time $t_{d}$ was varied in order to allow the system to reach equilibrium [10]. In detail, the optimized $\mathrm{E}_{\mathrm{d}}$ was determined by conducting several stripping experiments with several $E_{d}$ 's between 0.2 and $0.5 \mathrm{~V}_{\text {RHE }}$ and $t_{d}$ 's ranging from 1 to $600 \mathrm{~s}$. The optimized values for PC Ag were a $t_{d}$ of $300 \mathrm{~s}$ and an $E_{d}$ of $0.23 V_{R H E}$, respectively. Using these parameters the $\mathrm{Pb}$ stripping charge reached a maximum without any visible bulk deposition of $\mathrm{Pb}$ (see Figure 3A). Note, however, that these parameters may differ slightly for different NP Ag catalysts. The number of electrochemically accessible sites ( $\mathrm{N}_{\mathrm{ECAS}}$ ) was calculated from the stripping voltammogram assuming an one to one ratio of $\mathrm{Pb}$ to $\mathrm{Ag}$ atoms.

An additional methodology utilizing $\mathrm{Pb}(\mathrm{IV})$ species was employed to determine the surface charge for comparison. $\mathrm{Pb}(\mathrm{IV})$ forms an adsorbed monolayer on $\mathrm{Ag}$ electrodes dependent on the applied $\mathrm{E}_{\mathrm{d}}$ in the range of 1.15 to $1.20 \mathrm{~V}_{\mathrm{RHE}}$, and is observed in the negative going sweep by a reduction peak at $0.95 \mathrm{~V}_{\mathrm{RHE}}$ (see Figure $3 \mathrm{~B}$ ). If the deposition potential is increased beyond $1.19 \mathrm{~V}_{\mathrm{RHE}}$, lead-dioxide is formed (2) [28] and a $t_{d}$ dependent, second reduction peak occurs at $0.75 \mathrm{~V}_{\mathrm{RHE}}$.

$$
\mathrm{HPbO}_{2}^{-} \leftrightarrow \mathrm{PbO}_{2}+\mathrm{H}^{+}+2 \mathrm{e}^{-} \quad \mathrm{pH}>10
$$

Analogous to the optimization scheme used in $\mathrm{Pb}_{\text {upd }}$ stripping, the $\mathrm{E}_{\mathrm{d}}$ and $\mathrm{t}_{\mathrm{d}}$ parameters for $\mathrm{Pb}(\mathrm{IV})$ were found by maximizing the monolayer $\mathrm{Pb}(\mathrm{IV})$ stripping peak I, without forming the second reduction peak II (Figure 3B). $\mathrm{Pb}$ upd and $\mathrm{Pb}(\mathrm{IV})$ stripping measurements on $\mathrm{PC} \mathrm{Ag}$ reproducibly resulted in a charge density of $450 \mu \mathrm{C} \mathrm{\textrm {cm } ^ { - 2 }}$. This is slightly higher than the values reported in the literature, i.e. $400 \mu \mathrm{C} \mathrm{cm}^{-2}$ for $\mathrm{Pb}_{\text {upd }}$ [11], and $200 \mu \mathrm{C} \mathrm{cm}^{-2}$ for the one electron process $\mathrm{Tl}_{\text {upd }}$ [12], which might be due to a slightly roughened surface.

Figure 3C shows the optimized stripping voltammograms of $\mathrm{Pb}$ upd and $\mathrm{Pb}(\mathrm{IV})$ from a $\mathrm{NP} \mathrm{Ag}$ sample with $100 \mathrm{\mu g} \mathrm{cm}^{-2}$ loading, resulting in a surface charge density $\sigma_{\mathrm{q}, \mathrm{Pb}}=1.2 \mathrm{mC} \mathrm{cm}^{-2}$ and $\sigma_{\mathrm{q}, \mathrm{Pb}(\mathrm{IV})}=1.1 \mathrm{mC} \mathrm{cm}^{-2}$ respectively. The difference of less than $10 \%$ between the two stripping methods is due to the error in the correction of the capacitive currents and in the selection of the integration limits. Interestingly, it was observed that compared to $\mathrm{PC} \mathrm{Ag}$ the optimized $\mathrm{E}_{\mathrm{d}}$ values for $\mathrm{Pb}$ upd shifted $30 \mathrm{mV}$ more positive, whilst the $\mathrm{E}_{\mathrm{d}}$ for $\mathrm{Pb}$ (IV) shifted $30 \mathrm{mV}$ more negative. In further contrast to PC Ag, the stripping charge of NP Ag was found to decrease by $\sim 5 \%$ for consecutive $\mathrm{Pb}$ upd stripping measurements, which could be due to a partial detachment of particles. Note, that the post-ORR surface areas of the Ag particles in some cases diverted up to $30 \%$ from the surface areas determined before ORR. Since the particles are only attached to the substrate by weak electrostatic forces, these losses might be either due to the rotation during recording the ORR and the cell exchange procedure or due to Ag dissolution. Although both processes are difficult to distinguish during the measurement, the latter process was minimized by limiting the upper potential to1.05 $\mathrm{V}_{\mathrm{RHE}}$, where in the CV still no Ag oxide peaks are detected. In the case of a large discrepancy of the post-ORR surface area the data were not further evaluated. That is, the activities of only those measurements were analyzed, where the surface area loss within the measurement was negligible.

The surface area determination can be applied to probe the full accessibility of the catalyst surface, as proposed in the determination of mass activity. The results from the stripping experiments as a function of the NP Ag loading are shown in Figure 4. It can be seen that $\sigma_{\mathrm{q}}$ indeed depends linearly on the catalyst loading up to 
$200 \mu \mathrm{g} \mathrm{cm}^{-2}$; so all the catalyst is utilized and these samples can be used for determining the specific ORR activities. For higher loadings of $400 \mathrm{\mu g} \mathrm{cm}^{-2}$, however, the ratio deviates from the linear regression, so that specified mass activities lead to erroneous results and have to be discarded.

\section{Specific activity/Turnover Frequency}

After determining the electrochemically accessible sites, the surface area specific activity of the catalysts can be calculated by assuming a standard charging value per surface area for the material. However, for alloys or the recently reported $\mathrm{Fe} / \mathrm{N} / \mathrm{C}$ type of catalysts [1] the correct standard charging value is often problematic. For example for a Pt alloy system in alkaline solution the exact surface composition is in general not known and thus a standard value in terms of charge per surface area cannot be given. Instead, a normalization of the catalytic activity to the implicit charging/decharging value avoids such assumptions, resulting in an activity in the form of a turn over frequency (TOF) [29]. In the presented work both properties were determined; the TOF of the ORR by dividing the number of reacting molecules per unit time (determined by $\mathrm{i}_{\mathrm{f}}$ ) by the number of electrochemically accessible sites (determined by the Pb stripping charge measured after the ORR). The specific activity was calculated by multiplying the TOF value with $400 \mu \mathrm{C} \mathrm{cm}^{-2}$, i.e. the normalization constant of a two electron process for the surface area of PC Ag as given in the literature [11].

In Figure 5 the resulting TOF determined from the same 12 samples as in Figure 2 are plotted as a function of potential along with the TOF values obtained for PC Ag and PC Pt. Analogous to the standard deviation of the NP Ag mass activity, the deviation in the potential region of interest is below 10\%. Furthermore it can be seen that at $0.9 \mathrm{~V}_{\mathrm{RHE}}$ the TOF of NP Ag is $0.1 \mathrm{~Hz}$, equivalent to that of PC Ag and one order of magnitude less than PC Pt. At lower potentials, the difference in activity between Pt and Ag increases further due to the different Tafel slopes.

\section{Comparison}

The thorough evaluation of the NP Ag catalyst enables a comparison with activities of PC Pt and Ag from literature. The kinetic parameters of the ORR obtained in this work are summarized along with values from other references in Table 1. Although literature data for the ORR kinetic activity of PC Pt varies significantly, it is one of the most active materials and should serve as a benchmark for any comparison. In this work we obtained a TOF of $1 \mathrm{~Hz}$ at $0.9 \mathrm{~V}_{\mathrm{RHE}}$ on PC Pt, and a Tafel slope of $60 \mathrm{mV} \mathrm{dec}^{-1}$; these values compare reasonably well with literature values for Pt PC in perchloric acid electrolyte [6, 7]. Thus results from our laboratory indicate that there is a comparably small difference in the TOF on PC Pt in acid and alkaline solution. However, in the literature one order of magnitude lower TOF values are reported for the ORR in alkaline electrolyte [30-32]. In these previous studies contradictory values of the Tafel slope from 60 [32] up to $120 \mathrm{mV} \mathrm{dec}^{-1}$ [30, 31] are determined, demonstrating that even a basic system like PC Pt is subject to inconsistencies. It should be pointed out, that latter measurements were performed in standard electrochemical glass cells, allowing impurities from the glass to leach into the alkaline electrolyte $[9,13]$, whose detrimental effects on activity measurements cannot be ruled out.

Comparing the Ag data of this study with the literature, the TOF of PC Ag of $0.1 \mathrm{~Hz}$ at $0.9 \mathrm{~V}_{\mathrm{RHE}}$ is (as for PC Pt) up to one order of magnitude higher than previously reported [3, 24, 33]. Possible reasons for this are the 
complete reduction of $\mathrm{Ag}$, the $\mathrm{R}_{\mathrm{u}}$ compensation and the applied subtraction of the capacitive current. The reduction of silver has an enhancing effect on the ORR and the reduction potential used in this study is more negative than in previous studies. Furthermore the actual faradic current at $0.9 \mathrm{~V}_{\mathrm{RHE}}$ is small; consequently the measured total current is highly subjective to the influence of the capacitive currents, which therefore must be considered. The Tafel slopes obtained for PC Ag correspond well to the literature values for PC Ag [3, 24] and $\mathrm{Ag}$ single crystals [33]. Since in contrast to previous studies a compensation of $R_{u}$ was applied, increased activities and a linear Tafel slope were observed in a potential window of over $200 \mathrm{mV}$. Different Tafel slopes obtained in previous studies in a low and a high potential region are most likely an artefact of RDE measurements due to an improper $\mathrm{R}_{\mathrm{u}}$ compensation.

Previous studies on Ag nanoparticles have provided unsatisfactorily comparable activities, as the catalyst surface area was not measured, nor was the scalability of the activity with loading investigated [34, 35]. The mass activity for the NP Ag catalyst of this study is $2.0^{*} 10^{-6} \mathrm{~A} \mathrm{\mu g}^{-1}$. Interestingly, the Tafel slope of $\sim 120 \mathrm{mV} \mathrm{dec}^{-1}$ for unsupported NP Ag does not correspond to that of PC Ag of $90 \mathrm{mV} \mathrm{dec}{ }^{-1}$, while the TOF at $0.9 \mathrm{~V}_{\mathrm{RHE}}$ is identical. The reason for this behaviour is still unclear at this point.

Comparing Ag to Pt, it is evident that in alkaline solution the TOF on PC Ag at $0.9 \mathrm{~V}_{\mathrm{RHE}}$ is about one order of

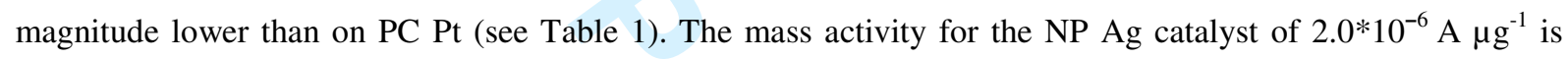
significantly lower than that of a state of the art carbon supported platinum high surface area catalyst. The divergence is partially due to the difference in particle size, i.e. $100 \mathrm{~nm}$ for $\mathrm{Ag}$ versus sub- $10 \mathrm{~nm}$ for Pt, and the therefore lower active surface area. So the mass activity of NP Ag could still be increased decisively by further reducing the particle size, as long as no eventually opposing particle size effect as for the ORR on Pt [36] appears. The Tafel slopes for NP Ag and PC Ag are, however, higher than the Tafel slope for Pt, which is clearly a disadvantage at higher overpotentials. Neglecting any other influence, such as long term stability, required catalyst film thickness in the MEA, etc., the economical conversion efficiency is quite similar. Albeit having one magnitude lower specific activity for ORR than platinum, $\mathrm{Ag}$ and alkaline based fuel cells might be a plausible candidate in future due to their lower cost.

\section{Conclusion}

We report a standardized ORR thin-film RDE study of a non-platinum catalyst, by applying a similar methodology as for platinum high surface area catalysts reported previously. A silver nanoparticle catalyst supported on glassy carbon is characterized with respect to the number of electrochemically accessible sites and the activity of oxygen reduction in alkaline solution. We have verified the full catalyst layer usage by the linear scaling of $\mathrm{N}_{\mathrm{ECAS}}$ and ORR activity with loading up to values of $200 \mu \mathrm{g} \mathrm{cm}^{-2}$. Due to the loading optimization and an adequate $\mathrm{R}_{\mathrm{u}}$-compensation, representative activities were obtained with high accuracy at fuel cell relevant potentials. Regarding the activity of the catalysts, no differences were found between the TOF of the NP Ag catalyst and PC Ag. The TOF on NP Ag and PC Ag at $0.9 \mathrm{~V}_{\mathrm{RHE}}$ is about one order of magnitude less than for PC Pt. Furthermore, it is established that the TOF on PC Pt in $0.1 \mathrm{M} \mathrm{KOH}$ and $0.1 \mathrm{M} \mathrm{HClO}_{4}$ do not vary significantly and exhibit the same Tafel slope of $60 \mathrm{mV} / \mathrm{dec}$. 


\section{Acknowledgement}

This work was supported by the DFG through the Emmy-Noether project ARE852/1-1. K.J.J. Mayrhofer expresses his gratitude to the Austrian FWF, which supported him with an Erwin-Schrödinger Scholarship. We thank Umicore AG \& Co. KG for the supply of the catalysts as well as fruitful discussions and S. Ashton for proofreading the manuscript. P. Niehoff and A. S. Crampton are acknowledged for their work in finding the measurement procedure. 


\begin{tabular}{|c|c|c|c|c|c|}
\hline Catalyst for ORR & $\begin{array}{c}\text { TOF } \\
(\log \mathrm{Hz}) \\
\text { at } 0.9 \mathrm{~V}_{\mathrm{RHE}}\end{array}$ & $\begin{array}{c}\text { Spec. Activity } \\
\left(\log \mathrm{A} / \mathrm{cm}_{\text {real }}^{2}\right) \\
\text { at } 0.9 \mathrm{~V}_{\mathrm{RHE}}\end{array}$ & $\begin{array}{c}\text { Mass Activity } \\
\left(\log \mathrm{A} / \mu \mathrm{g}_{\text {cat }}\right) \\
\text { at } 0.9 \mathrm{~V}_{\mathrm{RHE}}\end{array}$ & $\begin{array}{l}\text { Tafel Slope } \\
(\mathrm{mV} / \mathrm{dec})\end{array}$ & Reference \\
\hline $\begin{array}{l}\operatorname{Ag}(110) \\
\operatorname{Ag}(100)\end{array}$ & $\begin{array}{l}-1.1 \\
-1.6\end{array}$ & $\begin{array}{l}-4.4 \\
-4.7\end{array}$ & - & $\begin{array}{c}80 \\
\text { (cont. } \\
\text { changing) }\end{array}$ & [33] \\
\hline $\mathrm{PC} \mathrm{Ag}$ & $\begin{array}{l}-0.9 \\
-2.0\end{array}$ & $\begin{array}{l}-4.0 \\
\approx-5\end{array}$ & - & $\begin{array}{l}90 \\
90\end{array}$ & $\begin{array}{c}\text { This work } \\
{[3,24]}\end{array}$ \\
\hline NP Ag & -1.0 & -4.0 & -5.7 & 120 & This work \\
\hline $\mathrm{PC} \mathrm{Pt}$ & $\begin{array}{c}-0.1 \\
0.2 \\
0.6 \\
-0.9 \\
-0.6 \\
-1.3\end{array}$ & $\begin{array}{l}-3.1 \\
-2.9 \\
-2.6 \\
-4.0 \\
-3.7 \\
-4.4\end{array}$ & - & $\begin{array}{c}60 \\
60 \\
60 \\
104 \\
120 \\
60\end{array}$ & $\begin{array}{c}\text { This work } \\
{[7]^{\mathrm{a}}} \\
{[6]^{\mathrm{a} T}} \\
{[30]^{\mathrm{b}}} \\
{[31]^{\mathrm{b}}} \\
{[32]^{\mathrm{b}}}\end{array}$ \\
\hline $\begin{array}{c}\text { Pt/HSC-E } \\
45.9 \% \text { (TKK) }\end{array}$ & -0.7 & -3.7 & -4 & - & {$[6]^{\mathrm{aT}}$} \\
\hline
\end{tabular}

Table 1. ORR kinetic parameters on bulk Silver (PC Ag), platinum (PC Pt), and nanoparticles of Silver (NP Ag). The TOF from literature sources were calculated by dividing the specific area with the charge density for a one electron process on the specific material, i.e. $195 \mu \mathrm{C} \mathrm{cm}{ }^{-2}$ for Platinum [7], $200 \mu \mathrm{C}$

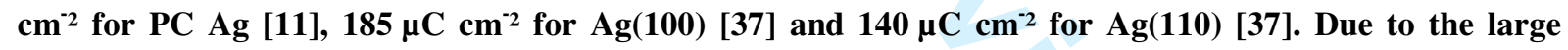
scatter of the data and for the sake of an easy comparison, the values are given with an accuracy of only one digit.

${ }^{\mathrm{a}}$ in acid electrolyte

${ }^{\mathrm{b}}$ in basic electrolyte

${ }^{\mathrm{T}}$ experiment at $60^{\circ} \mathrm{C}$ 
References

[1] M. Lefevre, E. Proietti, F. Jaouen, and J. P. Dodelet, Science (2009) 32471.

[2] H. A. Gasteiger and N. M. Markovic, Science (2009) 32448.

[3] D. Sepa, M. Vojnovic, and Damjanov.A, Electrochimica Acta (1970) 151355.

[4] M. A. García-Contreras, S. M. Fernández-Valverde, and J. R. Vargas-García, Journal of Alloys and Compounds (2007) 434-435 522.

[5] M. L. Calegaro, F. H. B. Lima, and E. A. Ticianelli, Journal of Power Sources (2006) 158735.

[6] H. A. Gasteiger, S. S. Kocha, B. Sompalli, and F. T. Wagner, Applied Catalysis B: Environmental (2005) 569.

[7] K. J. J. Mayrhofer, D. Strmcnik, B. B. Blizanac, V. Stamenkovic, M. Arenz, and N. M. Markovic, Electrochimica Acta (2008) 533181.

[8] S. Trasatti and O. A. Petrii, Pure \& Appl. Chern., Vol. 63, No. 5, pp. 71 1-734, 1991 (1991) 63711.

[9] K. J. J. Mayrhofer, G. K. H. Wiberg, and M. Arenz, Journal of The Electrochemical Society (2008) 155 P1.

[10] C. L. Green and A. Kucernak, Journal of Physical Chemistry B (2002) 1061036.

[11] E. Kirowa-Eisner, Y. Bonfil, D. Tzur, and E. Gileadi, Journal of Electroanalytical Chemistry (2003) 552171.

[12] V. Daujotis and E. Gaidamauskas, Journal of Electroanalytical Chemistry (1998) 446151.

[13] K. J. J. Mayrhofer, A. S. Crampton, G. K. H. Wiberg, and M. Arenz, Journal of The Electrochemical Society (2008) 155 P78.

[14] K. J. J. Mayrhofer, S. J. Ashton, J. Kreuzer, and M. Arenz, International Journal of Electrochemical Science (2009) 41.

[15] H. Shin and C. Kang, Analytical Sciences (2003) 191667.

[16] J. H. Vleeming, B. F. M. Kuster, G. B. Marin, F. Oudet, and P. Courtine, Journal of Catalysis (1997) 166148.

[17] W. Oelßner, F. Berthold, and U. Guth, Materials and Corrosion (2006) 57455.

[18] J. M. M. Droog, P. T. Alderliesten, and G. A. Bootsma, Journal of Electroanalytical Chemistry (1979) 99173.

[19] B. M. Jovic, V. D. Jovic, and G. R. Stafford, Electrochemistry Communications (1999) 1247.

[20] R. D. Giles and J. A. Harrison, Journal of Electroanalytical Chemistry (1970) 27161.

[21] H. Tae Uk and C. Won Sub, Journal of The Electrochemical Society (2005) 152 A996.

[22] H. Tae Uk and C. Won Sub, Journal of The Electrochemical Society (2005) 152 A179.

[23] B. J. Murray, Q. Li, J. T. Newberg, E. J. Menke, J. C. Hemminger, and R. M. Penner, Nano Lett. (2005) 52319.

[24] T. Hurlen, Y. L. Sandler, and E. A. Pantier, Electrochimica Acta (1966) 111463.

[25] R. E. Davis, G. L. Horvath, and C. W. Tobias, Electrochimica Acta (1967) 12287.

[26] E. Kirowa-Eisner, D. Tzur, and E. Gileadi, Journal of Electroanalytical Chemistry (2008) In Press, Corrected Proof.

[27] E. Kirowa-Eisner, R. Gepshtein, and E. Gileadi, Journal of Electroanalytical Chemistry (2005) 583 273.

[28] M. Pourbaix, Atlas of Electrochemical Equilibria in aqueous solutions, Pergamon Press, 1966.

[29] R. L. J. Burwell, Pure and Applied Chemistry (1976) 4671.

[30] G. Couturier, D. W. Kirk, P. J. Hyde, and S. Srinivasan, Electrochimica Acta (1987) 32995.

[31] K. L. Hsueh, E. R. Gonzalez, and S. Srinivasan, Electrochimica Acta (1983) 28691.

[32] K. Tammeveski, T. Tenno, J. Claret, and C. Ferrater, Electrochimica Acta (1997) 42893.

[33] B. B. Blizanac, P. N. Ross, and N. M. Markovic, J. Phys. Chem. B (2006) 1104735.

[34] M. Chatenet, L. Genies-Bultel, M. Aurousseau, R. Durand, and F. Andolfatto, Journal of Applied Electrochemistry (2002) 321131.

[35] L. Demarconnay, C. Coutanceau, and J. M. Léger, Electrochimica Acta (2004) 494513.

[36] K. J. J. Mayrhofer, B. B. Blizanac, M. Arenz, V. R. Stamenkovic, P. N. Ross, and N. M. Markovic, Journal of Physical Chemistry B (2005) 10914433.

[37] D. Dickertmann, F. D. Koppitz, and J. W. Schultze, Electrochimica Acta (1976) 21967. 

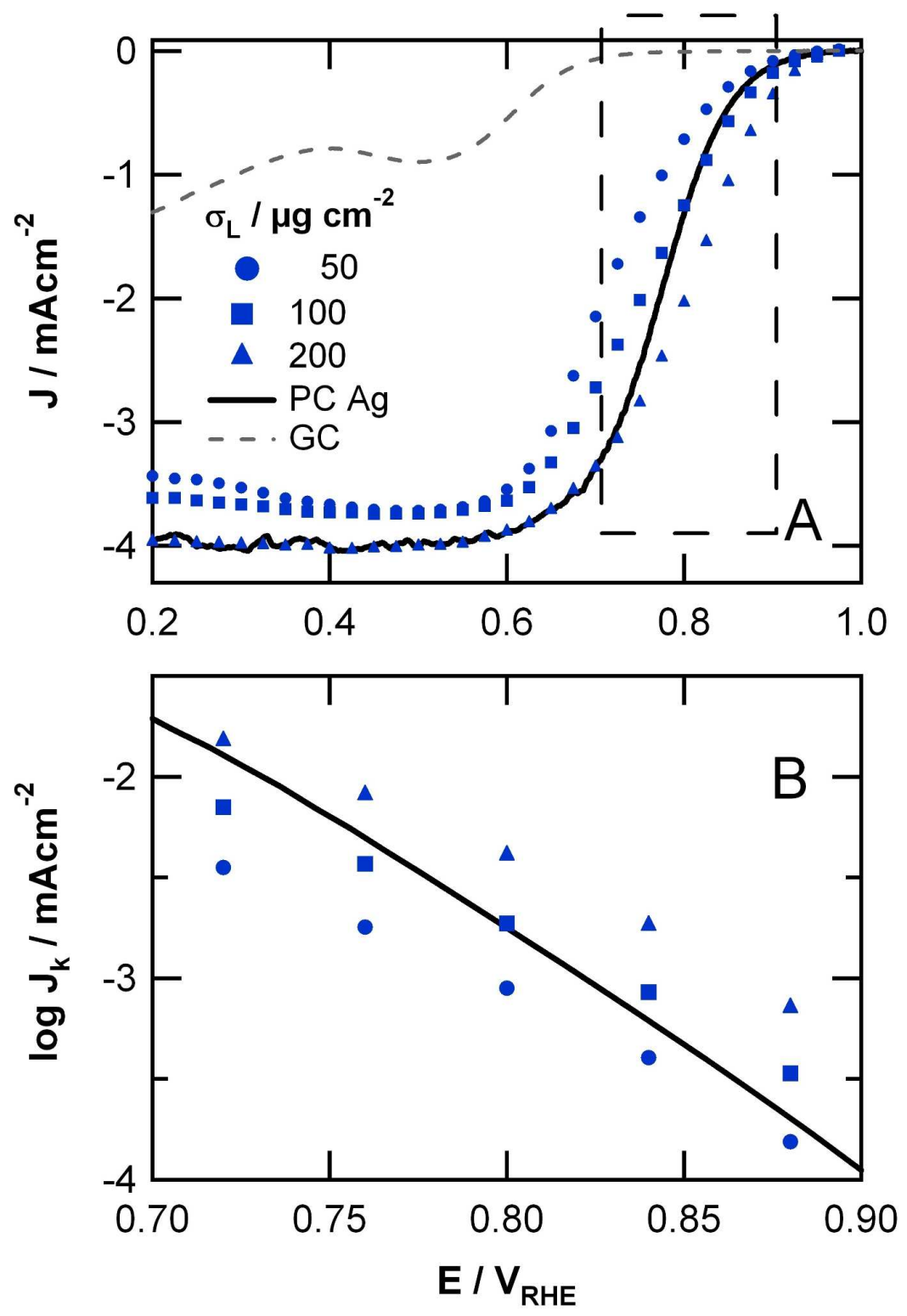

Figure 1 (A) Ru-compensated and capacitive current corrected polarization curves recorded in oxygen saturated $0.1 \mathrm{M} \mathrm{KOH}$ solution at a rotation rate of $900 \mathrm{rpm}$ for NP Ag with 50, 100 and 200 $\mu \mathrm{C} \mathrm{cm}-2$ loadings as well as PC Ag and bare GC. The scan rate was $100 \mathrm{mV} \mathrm{s}-1$. (B) Tafel plot of total kinetic current densities obtained from the polarization curves shown in $(A)$. $119 \times 174 \mathrm{~mm}(600 \times 600 \mathrm{DPI})$ 


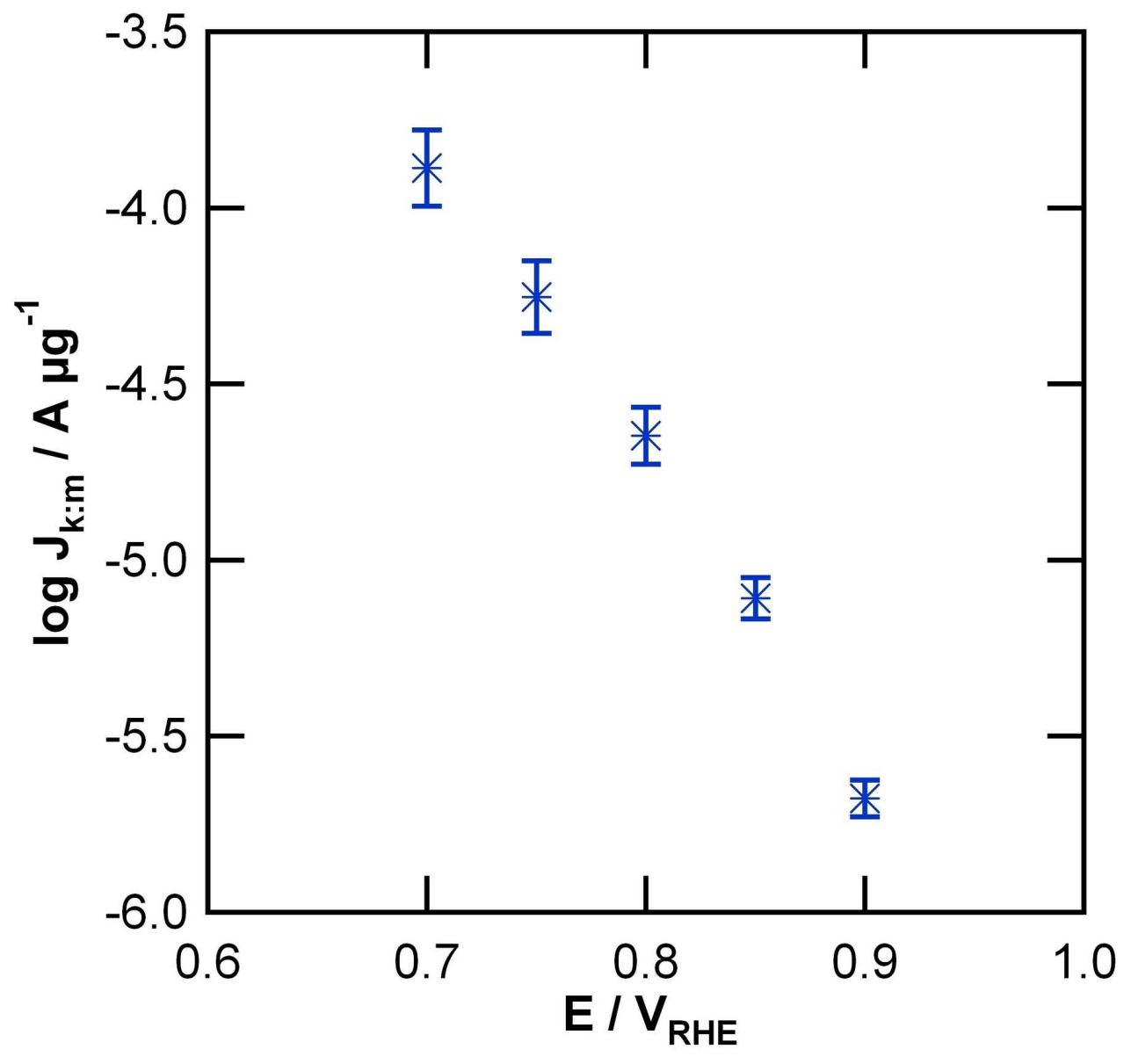

Figure 2. Tafel plot the kinetic current density of the ORR normalized to the metal loading of NP Ag (mass activity) obtained from 12 independent measurements with different loadings between 50 and $200 \mu \mathrm{g} \mathrm{cm}-2$.

$79 \times 77 \mathrm{~mm}(600 \times 600 \mathrm{DPI})$ 

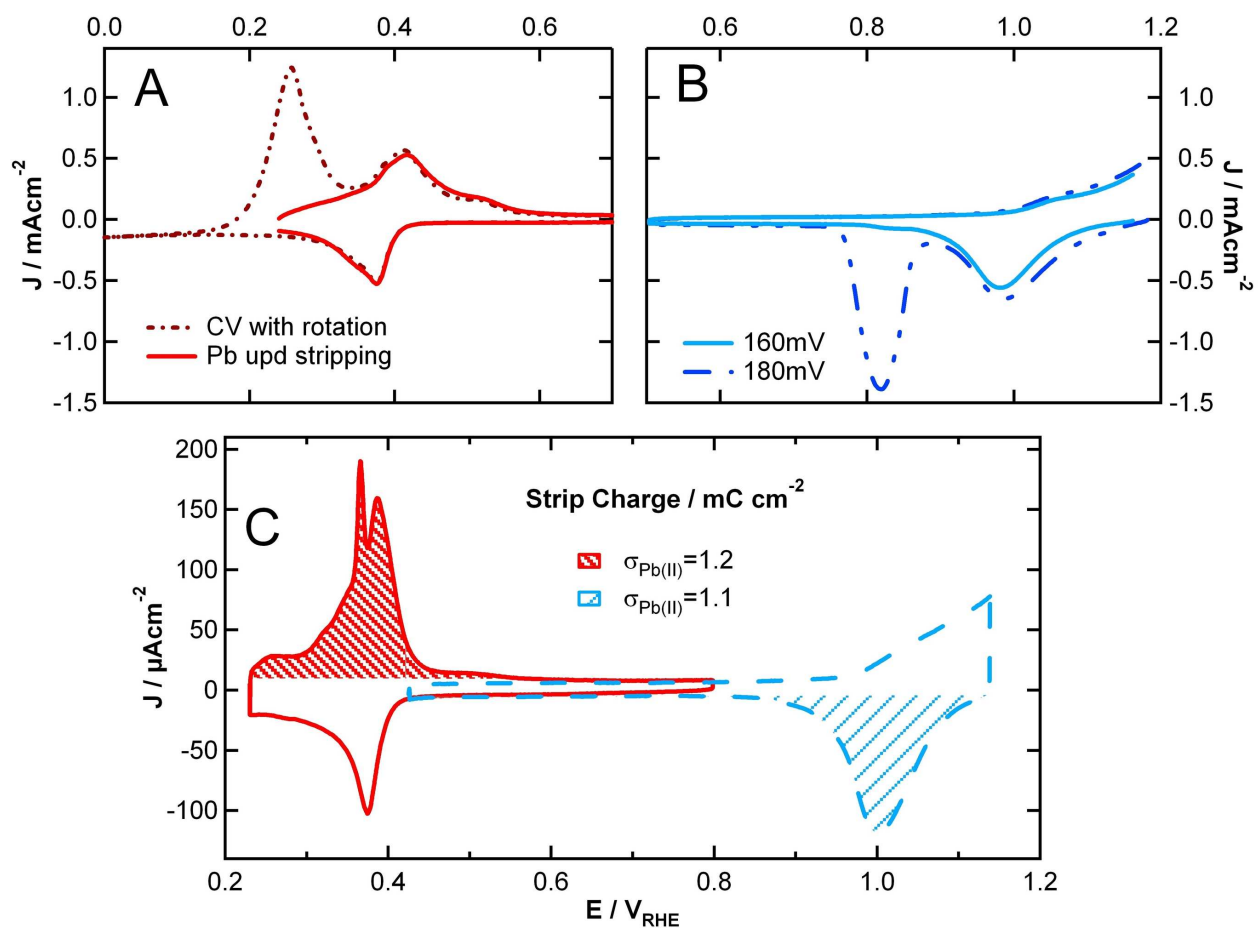

Figure 3. Voltammograms of a PC Ag electrode recorded with $0.1 \mathrm{~V} \mathrm{~s}-1$ in Ar-saturated $0.1 \mathrm{M} \mathrm{KOH}+$ $125 \mu \mathrm{M} \mathrm{Pb}(\mathrm{NO} 3) 2$ solution; (A) strip voltammogram after $180 \mathrm{~s}$ at $\mathrm{Ed}=0.23 \mathrm{VRHE}$ (solid line), consecutive voltammogram recorded with more negative potential limit and rotation rate of 900 rpm (dotted line). (B) Pb(IV) stripping curves recorded at Ed $=1.160$ and 1.180 VRHE. (C) Optimized strip voltammogram of $\mathrm{Pb}$ upd (left) and $\mathrm{Pb}$ (IV) (right) at $10 \mathrm{mV} \mathrm{s}-1$ from NP Ag sample with loading $100 \mu \mathrm{g} \mathrm{cm}-2$. Shaded areas indicate the corresponding charges. $119 \times 89 \mathrm{~mm}(600 \times 600 \mathrm{DPI})$ 


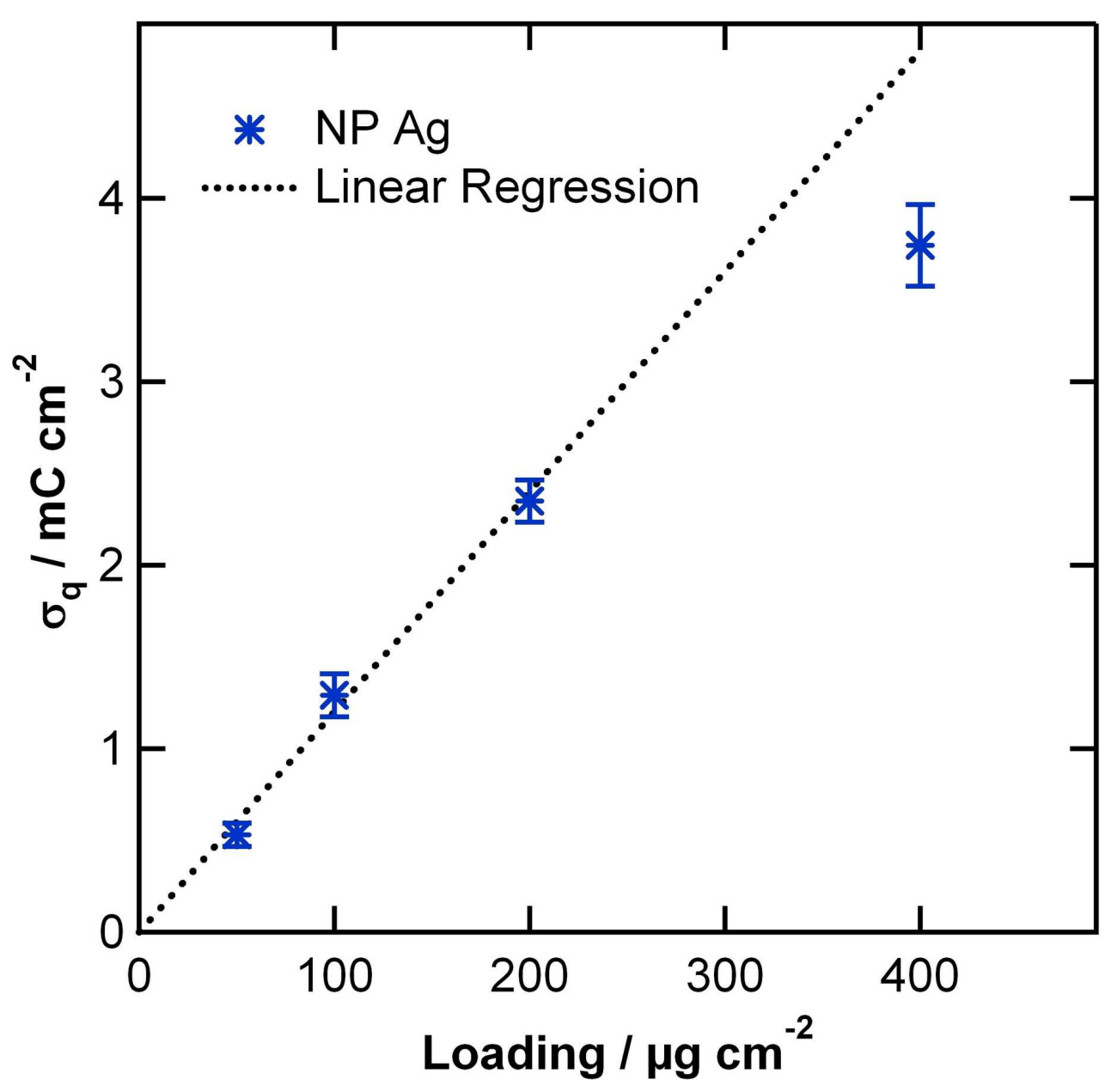

Figure 4. Charge density oq of NP Ag as a function of the catalyst loadings determined by $\mathrm{Pb}$ stripping in several independent measurements according to method described in the text. The dotted black line indicates a linear regression (loading of $400 \mu \mathrm{gcm}-2$ is not included); The slope is $12 \mathrm{C} \mathrm{g}-1$.

$79 \times 77 \mathrm{~mm}(600 \times 600 \mathrm{DPI})$ 


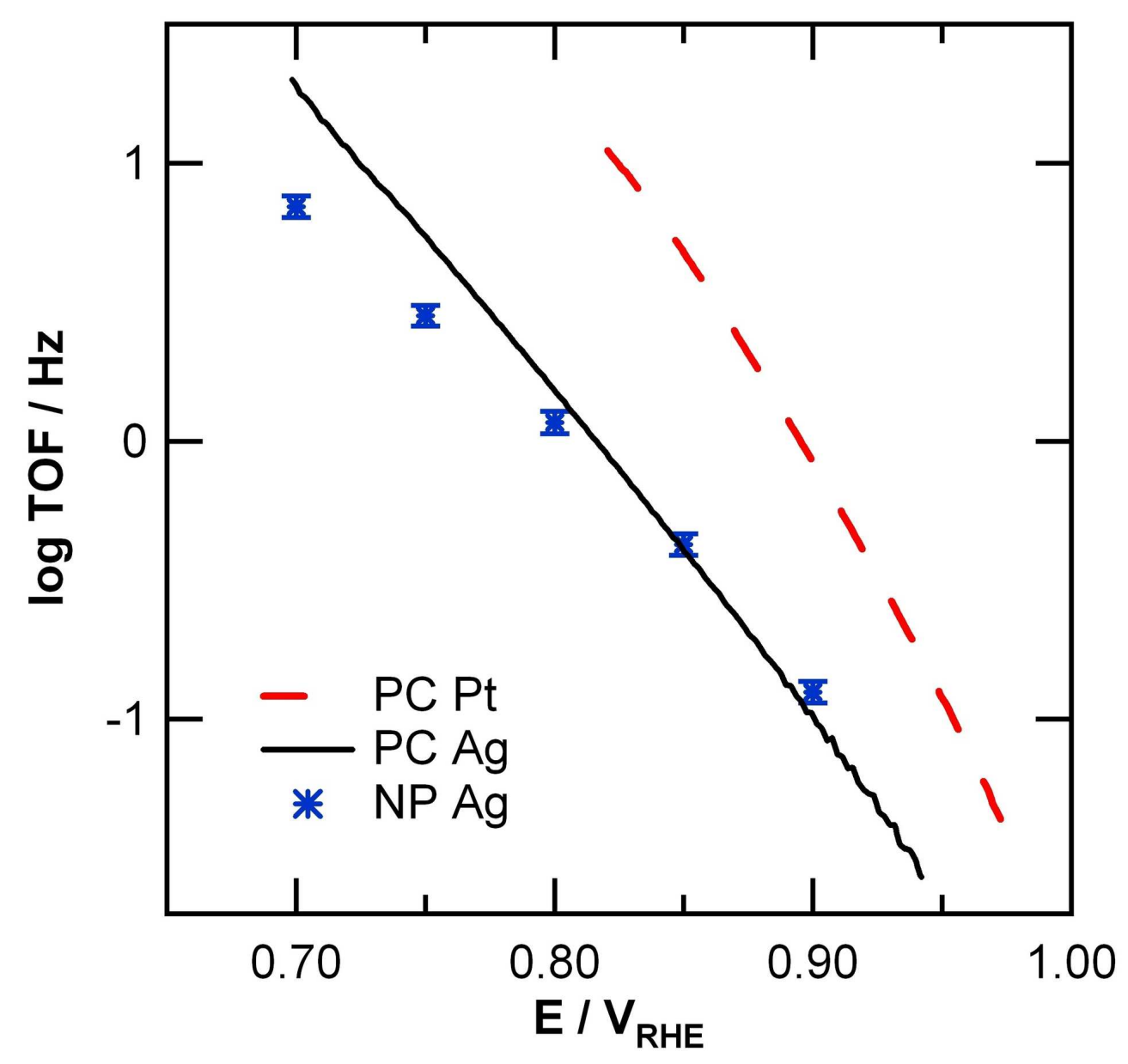

Figure 5. Tafel plot of the turn over frequency of the ORR on NP Ag (blue marker), PC Ag (solid line) and PC Pt (dashed line) in $0.1 \mathrm{M} \mathrm{KOH}$. $82 \times 82 \mathrm{~mm}(600 \times 600 \mathrm{DPI})$ 